Journal of Health Promotion and Behavior (2017), 2(1): 88-97

https://doi.org/10.26911/thejhpb.2017.02.01.08

\title{
Biopsychosocial and Economic Determinants of Condom Use among Gay in Tulungagung District, East Java
}

\author{
Fransisca Novalia Permana', Argyo Demartoto'), Bhisma Murti1) \\ ${ }^{1)}$ Masters Program in Public Health, Sebelas Maret University, Surakarta \\ ${ }^{2)}$ Study Program in Sociology, Faculty of Social and Political Sciences, \\ Sebelas Maret University, Surakarta
}

\begin{abstract}
Background: HIV/ AIDS epidemics emerged among men who have sex with men, particularly among gay, due to unsafe anal sex practice. As studies have shown having sex without condom increases the risk of HIV/ AIDS 18 times as many as per-vaginal sex. This study aimed to examine biopsychosocial and economic determinants of condom use among gay in Tulungagung district, East Java.

Subjects dan Method: This was an analytic observational study using cross-sectional design. The study was conducted in Tulungagung district, East Java, from January to February 2017. A sample of 165 gays was selected by random sampling out of all 300 gays in the community. The independent variables were perceived susceptibility, perceived seriousness, perceived benefit, perceived barrier, and self- efficacy. The dependent variable was condom use. The data were collected by a set of pre-tested questionnaire, and analyzed by multiple logistic regression.

Results: Perceived seriousness $(\mathrm{OR}=2.83 ; 95 \% \mathrm{CI}=1.14$ to $7.04 ; \mathrm{p}=0.025)$, perceived benefit $(\mathrm{OR}=$ 4.90; $95 \% \mathrm{CI}=2.11$ to 11.36 ; $\mathrm{p}<0.001)$, self-efficacy ( $\mathrm{OR}=4.48 ; 95 \% \mathrm{CI}=2.03$ to $9.89 ; \mathrm{p}<0.001)$, increased the likelihood of condom use. Perceived susceptibility $(\mathrm{OR}=1.02 ; 95 \% \mathrm{CI}=0.40$ to 2.59 ; $\mathrm{p}=0.972$ ) increased the likelihood of condom use, although it was not statistically significant. Perceived barrier ( $\mathrm{OR}=0.36 ; 95 \% \mathrm{CI}=0.13$ to $1.00 ; \mathrm{p}=0.050)$ decreased the likelihood of condom use, and it was statistically significant.

Conclusion: Perceived seriousness, perceived benefit, and self- efficacy, increased the likelihood of condom use among gay. Perceived barrier decreased the likelihood of condom use.
\end{abstract}

Keywords: biopsychosocial, determinant, condom use, HIV/ AIDS, Gay

\section{Correspondence:}

Fransisca Novalia Permana. Masters Program in Public Health, Sebelas Maret University, Surakarta. Email: fransisca2713@gmail.com. Mobile: +6285645762007.

\section{BACKGROUND}

HIV/ AIDS at present is becoming serious global health problem (WHO, 2015). HIV or Human Immuno Deficiency Virus is a virus destroying white blood cell within human body. Whereas AIDS or Acquired Immune Deficiency Syndrome is a series of illnesses which are generated by HIV (Kemenkes RI, 2014; WHO, 2016).

In 2015 there were 36.7 million who were infected with HIV globally, and 2.1 million people became newly infected with HIV (WHO, 2015). Initial stage of the epi- demic, the disease was likely to be heterosexually identified, however the current data shows that in developing countries, homosexual, that is men who have sex with men, is likely to cause more transmission of HIV (Amirkhanian et al, 2010). In 2015 it was estimated 3.5 million people who were infected with HIV in Asia. (WHO, 2015). In South East Asia HIV prevalence on men who have sex with men (MSM) is escalating rapidly with Thailand at the first rank (UNAIDS, 2008). 
Since HIV has been found in 1987 up to present day, the number of sufferers is getting escalating. The cumulative number of HIV infection that had been reported up to 2016 was $198,219 \mathrm{HIV}$ infection cases with Special Capital Region of Jakarta (40, 500 ) at the top chart, followed by East Java $(26,052)$ and Papua $(21,474)$. The majority HIV transmission risk factors were heterosexually $(51,692)$, IDUs $(8,835)$, MSM (2, 304), mother-to-child (2,226), bisexual (399), and blood transfusion (201). The most AIDS cases was in East Java $(13,623)$ followed with Papua (13,328) and Special Capital Region of Jakarta $(8,093)$ (Kemenkes RI, 2016).

In East Java the highest number of people who were infected with HIV was in Surabaya (7,045), Malang (2,693), Jember $(2,489)$, Banyuwangi $(2,379)$ and Tulungagung (1,465) (Dinkes Jatim, 2015). Based on preliminary study conducted in Tulungagung in November 2016 from the last data of September 2016 the number of HIV/ AIDS cases was 1,480 with number of men was $55.13 \%$ and women was $44.87 \%$. The HIV cases in Tulungagung mostly caused by female sex workers (511), men who have sex with men (MSM) which was gay men (31), transvestites (18), IDUs (18), perinatal (30), and others 872 cases. HIV cases in Tulungagung Regency keeps on escalating and becoming major problem that should be overcome, including HIV cases among gay men in Tulungagung Regency (KPA Kabupaten Tulungagung, 2016).

The reasons of recurrence of HIV epidemic among gay men include high level of unprotected sexual behavior that involves people who do not know about their infection status and do not take any medicine. Unprotected sexual behavior is using no condom during anal sex that involves men with undiagnosed HIV/ AIDS (Spiritia, 2012). Sexual behavior among gay men of- ten transmits HIV/AIDS through oral and anal sex (Liu et al, 2012). Anal sex without condom is 18 times more likely to transmit HIV than vaginal sex, either among gay men or heterosexual couples. Condom which is properly and consistently used is very effective in preventing HIV and Sexual Transmitted Disease (STD) (WHO, 2009).

Target of condom use promotion is not only common people, but also people who are in high risk of being exposed by HIV such as sex workers and their customers, IDUs, gay men, and transvestites (UNAIDS, 2004). Factor of inconsistent condom use among gay men has been stated as an obstacle, similar to the knowledge on HIV/AIDS transmission and the absence of support from sexual partners (Ramanathan et al., 2013).

Some gay men in China decided to commit suicide if they happen to get infected with HIV/AIDS, it became a motivation to use condom during sexual intercourse (Liu et al., 2012). There is perceived vulnerability that is a gay man use condom as an effort to reduce the vulnerability toward HIV (Belcher et al, 2005). It is supported by perceived severity, by using condom even using double condoms whenever they believe their sexual partner is not safe or has been infected with HIV/AIDS or looks dirty (Liu et al., 2012).

Harawa et al (2006), states that condom use by gay men is determined by subjective perception on the advantages and disadvantages of condom use. Researchers studied the biopsychosocial economic determinant among gay men by using Health Belief Model Theory. The study aimed to explain the influence of biopsychosocial economic determinant toward condom use among gay men in Tulungagung Regency. 
Journal of Health Promotion and Behavior (2017), 2(1): 88-97

https://doi.org/10.26911/thejhpb.2017.02.01.08

\section{SUBJECTS AND METHOD}

\section{Research Design}

The study design used in this study was analytic observational with cross sectional approach. The study was conducted in January and February 2017 in Tulungagung Regency

\section{Population and Sample}

The population in general was the entire gay men, whereas targeted population was the members of Pelangi gay community that consisted of 300 people which is limited by inclusion and exclusion criteria.

There were a total of 165 subjects which were selected by probability sampling technique with simple random sampling type. The data collection technique used was questionnaires and the data processing used was multiple logistic regression.

\section{Variables Research}

Independent variables of the study were perceived vulnerability, perceived severity, perceived benefits, perceived obstacles and self efficacy. Independent variable was condom use.

Data collection was conducted in observation by using questionnaires. It consisted of favorable and unfavorable questions that had been through face validity and content validity and reliability test of alpha cronbach $\geq 0.60$.

Variables in the study were perceived vulnerability $(\mathrm{O}=$ not vulnerable, $1=$ vulnerable), perceived severity ( $\mathrm{O}=$ not severe, $1=$ severe), perceived benefits ( $O=$ not beneficial, $1=$ beneficial $)$, perceived obstacles $(0=$ with obstacles, $1=$ without obstacles), self efficacy $(0=$ poor self efficacy, $1=$ strong self efficacy), condom use ( $0=$ not always, $1=$ always).

The researchers considered the research ethics, namely the distribution of inform consent, which meant an approval sheet given to research subjects to know the intention of the research, anonymity that was without mentioning the name of research subject, confidentiality which meant keeping the information given by research subjects restricted.

\section{Data analysis}

Data processing was conducted by using editing technique which meant reexamine the instruments filled out by research subjects, scoring was giving value on each question item and sum up them up, data coding was giving code to research data for statistic analysis, data entry was putting the data out of the questionnaires into computer in accordance with statistics data, tabulating was data processing that aimed to make table that may give statistics illustration.

Data analysis technique consisted of univariate analysis that aimed to explain characteristics of each data. Bivariate analysis aimed to analyze the relationship of two variables using chi square test with 2x2 contingency table to discover how big the influence of dependent over independent. Multivariate analysis with multiple logistic regressions aimed to measure the influence of more than one independent variables toward dependent variable. The intensity of association was presented by the value of OR and CI.

\section{RESULTS}

Characteristics of research subjects in Table 1 were the result of univariate analysis. Data in Table 1 showed that out of 165 research subjects half of them were between 20-35 years which was as many as 98 people (59.39\%), those who were $<20$ years were 65 (39.39\%), whereas $>35$ tahun were 2 (1.21\%). Based on education, the obtained data showed that half of the research subjects' education was $\geq$ High School which was as many as 155 people (93.9) whereas there were 10 (6.1) whose education $<$ High 
School. Based on occupation, the obtained data showed that most of the research subjects did not work, which was as many as 102 (61.8\%), whereas 63 (38.2\%) research subjects worked. Based on income, the data was obtained that almost all research subjects had income $<$ UMR $(<\mathrm{Rp}$ $1,537,150)$ which was 147 (89.1\%) people and research subjects who had income $\geq$ UMR were 18 (10.9\%) people.

Table 1. Characteristics of Research Subjects

\begin{tabular}{|c|c|c|c|}
\hline Characteristics & Criteria & $\mathbf{n}$ & $\%$ \\
\hline \multirow[t]{3}{*}{ Age } & $<20$ years & 65 & 39.4 \\
\hline & 20-35 years & 98 & 59.4 \\
\hline & $>35$ years & 2 & 1.2 \\
\hline \multirow[t]{2}{*}{ Education } & $<$ High School & 10 & 6.1 \\
\hline & $\geq$ High School & 155 & 93.9 \\
\hline \multirow[t]{2}{*}{ Occupation } & Unemployed & 102 & 61.8 \\
\hline & Employed & 63 & 38.2 \\
\hline \multirow[t]{2}{*}{ Income } & $\begin{array}{l}<\text { Regional } \\
\text { Minimum Wage }\end{array}$ & 147 & 89.1 \\
\hline & $\begin{array}{l}\geq \text { Regional } \\
\text { Minimum Wage }\end{array}$ & 18 & 10.9 \\
\hline \multirow[t]{2}{*}{ Marital Status } & Single & 151 & 91.5 \\
\hline & Married & 14 & 8.5 \\
\hline
\end{tabular}

Table 2. showed the result of bivariate analysis on the influence of one independent variable toward dependent variable. Independent variables of the study were perceived vulnerability, perceived severity, perceived benefits, perceived obstacles, and self efficacy. Dependent variable of the study was condom use.

Table 2. Bivariate analysis on independent variables with dependent variable

\begin{tabular}{|c|c|c|c|c|c|c|c|}
\hline \multirow[b]{2}{*}{ Variables } & \multirow[b]{2}{*}{ Criteria } & \multicolumn{2}{|c|}{ Condom Use } & \multirow[b]{2}{*}{ OR } & \multicolumn{2}{|c|}{ CI (95\%) } & \multirow[b]{2}{*}{$\mathbf{p}$} \\
\hline & & No (\%) & Yes (\%) & & $\begin{array}{l}\text { Lower } \\
\text { Limit }\end{array}$ & $\begin{array}{l}\text { Upper } \\
\text { Limit }\end{array}$ & \\
\hline \multirow{2}{*}{$\begin{array}{l}\text { Perceived } \\
\text { Vulnerability }\end{array}$} & $\begin{array}{l}\text { Not } \\
\text { vulnerable }\end{array}$ & 65 (50.0\%) & 65 (50.0\%) & \multirow[t]{2}{*}{0.67} & \multirow[t]{2}{*}{0.31} & \multirow[t]{2}{*}{1.42} & \multirow[t]{2}{*}{0.293} \\
\hline & Vulnerable & $14(40.0 \%)$ & $21(60.0 \%)$ & & & & \\
\hline \multirow{2}{*}{$\begin{array}{l}\text { Perceived } \\
\text { Severity }\end{array}$} & Not Serious & $35(72.9 \%)$ & $13(27.1 \%)$ & \multirow[t]{2}{*}{0.22} & \multirow[t]{2}{*}{0.11} & \multirow[t]{2}{*}{0.47} & \multirow[t]{2}{*}{$<0.001$} \\
\hline & Serious & $44(37.6 \%)$ & $73(62.4 \%)$ & & & & \\
\hline \multirow{2}{*}{$\begin{array}{l}\text { Perceived } \\
\text { Benefits }\end{array}$} & Not & $63(59.4 \%)$ & $43(40.6 \%)$ & \multirow[t]{2}{*}{0.25} & \multirow[t]{2}{*}{0.13} & \multirow[t]{2}{*}{0.51} & \multirow[t]{2}{*}{$<0.001$} \\
\hline & $\begin{array}{l}\text { Beneficial } \\
\text { Beneficial }\end{array}$ & $16(271 \%)$ & $43(72.9 \%)$ & & & & \\
\hline \multirow{3}{*}{$\begin{array}{l}\text { Perceived } \\
\text { Obstacles }\end{array}$} & With & $72(55.0 \%)$ & $59(45.0 \%)$ & \multirow{3}{*}{4.71} & \multirow{3}{*}{1.91} & \multirow{3}{*}{11.57} & \multirow{3}{*}{$<0.001$} \\
\hline & obstacles & & & & & & \\
\hline & $\begin{array}{l}\text { Without } \\
\text { Obstacles }\end{array}$ & $7(20.6 \%)$ & $27(79.4 \%)$ & & & & \\
\hline \multirow{2}{*}{ Self Efficacy } & Poor Self & $55(68.8 \%)$ & $25(31.3 \%)$ & \multirow[t]{2}{*}{0.18} & \multirow[t]{2}{*}{0.92} & \multirow[t]{2}{*}{0.35} & \multirow[t]{2}{*}{$<0.001$} \\
\hline & $\begin{array}{l}\text { Strong Self } \\
\text { Efficacy }\end{array}$ & $24(28.2 \%)$ & $61(71.8 \%)$ & & & & \\
\hline
\end{tabular}

Gay men who had perceived vulnerability toward disease were 0.67 times likely to use condom than those who did not have perceived vulnerability toward disease. The 
Journal of Health Promotion and Behavior (2017), 2(1): 88-97

https://doi.org/10.26911/thejhpb.2017.02.01.08

result $(\mathrm{p}=0.010)$ meant there was no influence of gay men's perceived vulnerability toward condom use.

Gay men who had perceived seriousness toward disease were 0.22 times likely to use condom than those who did not have perceived seriousness toward disease. The result ( $\mathrm{p}<0.001)$ meant there was influence of gay men's perceived seriousness toward condom use.

Gay men who had perceived benefits were 0.25 times likely to use condom than those who did not have perceived benefits. The result $(\mathrm{p}<0.001)$ meant that there was influence of gay men's perceived benefits toward condom use
Gay men who had perceived obstacles were 4.71 times likely to use condom than those who did not have perceived obstacles. The result $(\mathrm{p}<0.001)$ meant that there was influence of gay men's perceived obstacles toward condom use.

Gay men who had strong self efficacy toward condom were 0.18 times likely to use condom than those who had poor self efficacy. The result $(\mathrm{p}<0.001)$ meant that there was influence of gay men's self efficacy toward condom use.

Table 3 was data of multivariate analysis on some variables related with dependent variable.

Table 3 The result of multivariate analysis with multiple logistic regression

\begin{tabular}{|c|c|c|c|c|}
\hline \multirow{2}{*}{ Variables } & \multirow{2}{*}{ OR } & \multicolumn{2}{|c|}{ CI 95\% } & \multirow[b]{2}{*}{$\mathbf{p}$} \\
\hline & & Lower Limit & Upper Limit & \\
\hline Perceived vulnerability (high) & 1.02 & 0.40 & 2.59 & 0.972 \\
\hline Perceived severity (high) & 2.83 & 1.14 & 7.04 & 0.025 \\
\hline Perceived benefits (high) & 4.90 & 2.11 & 11.36 & $<0.001$ \\
\hline Perceived obstacles (high) & 0.36 & 0.13 & 1.00 & 0.050 \\
\hline Self Efficacy (strong) & 4.48 & 2.03 & 9.89 & $<0.001$ \\
\hline $\mathrm{N}$ observation & 165 & & & \\
\hline -2 log likelihood & 172.136 & & & \\
\hline Nagelkerke $\mathrm{R}^{2}$ & $38.6 \%$ & & & \\
\hline
\end{tabular}

Table 3 explained the result of multivariate analysis between independent variables toward dependent variable such as perceived vulnerability $(\mathrm{OR}=1.02$; CI $95 \%=0.40-$ 2.59; $\mathrm{p}=0.972$ ) increased the use of condom on gay men although statistically insignificant. Perceived severity $(\mathrm{OR}=2.83$; CI 95\% $=1.14-7.04 ; \mathrm{p}=0.025$ ) increased the condom use on gay men and statistically insignificant. Perceived benefits $(\mathrm{OR}=4.90$; CI $95 \%=2.11-11.36 ; \mathrm{p}<0.001)$ increased the condom use on gay men and statistically significant. Perceived obstacles $(\mathrm{OR}=0.6$; CI 95\% $=0.13-1.00 ; \mathrm{p}=0.050)$ decreased the use of condom on gay men and statistically significant. Self efficacy (OR= 4.48; CI 95\% $=2.03-9.89 ; \mathrm{p}<0.001)$ increased the use of condom on gay men and statistically significant.

\section{DISCUSSION}

\section{The Influence of Perceived Vulne- rability toward condom use among gay men}

Perceived vulnerability does not influence the use of condom among gay. Members of the community were more concerned with their own and their partners' pleasure when having sexual intercourse by frequently not using condom. Although we they had understood that they would be vulnerable to sexual transmitted diseases as well as HIV/ AIDS if they did not use condom. The strong attraction to their permanent partners who they believed were not infected 
with HIV/ AIDS led them to seldom use condom when they had sex. The thought if they were infected with HIV, the medicine was available and could be accessed in hospitals or clinics so that they still could prolong their life expectation.

Rosenstock (1988), states perceived vulnerability in Health Belief Model is one of the factors that encourage someone to lead healthy life.

The study is in accordance with a study conducted by McDaid et al (2010), that the government, civil society organization have attempted to give information about HIV prevention and transmission by means of print media, radio, television, as well as coaching with skilful cadres. However there are a lot of participants who do not attend and are not yet well-informed so that it is possible that the use of condom by gay men is still low. Enggarwati (2015), states that the more someone is at risk for a disease, does not necessarily make one conduct prevention action.

The study is unlike the study by Belcher et al (2005), that conveys a gay man who uses condom is as an effort to reduce the vulnerability to HIV

\section{The influence of perceived severity toward condom use among gay men}

Perceived severity influences the use of condom. The community understood that HIV/AIDS can be transmitted through high risk sexual behavior and it may lead to death. Someone who suffers from HIV/ AIDS will be excommunicated by family, society, and friends because general people do not know appropriately how HIV/AIDS is transmitted. They only know that if someone suffers from HIV/AIDS means they should avoid the person since it is contagious and may lead to death. When the feeling of afraid to be excommunicated comes to mind, it will encourage the mem- bers of community to use condom consistently despite the pleasure of sex without condom.

Perceived severity is an individual belief on disease severity or seriousness. It is based on health information or knowledge that may come from the difficulties of the disease which gives impact to our life (McCormick-Brown, 1999).

The study is similar with Satyabakti (2016), that states HIV/ AIDS is a dangerous disease. As gay, they often change sex partner and do not use condom consistently, it leads them to be at high risk for HIV/ AIDS. This perception generates the feeling of threatened and fear of being infected, thus influences gay men to use condom during sexual intercourse.

Eda et al (2012), states that perceived severity of HIV/ AIDS will affect someone in doing prevention effort since they think it is better to prevent than to get infected with incurable disease.

Different study conducted by Siahaan (2009), states that many of gay men already discover the effect of not using condom that is they may get infected with HIV/ AIDS and other sexual diseases that need complicated medication and therapy. HIV/ AIDS is incurable, there is no medicine yet for it. However it does not make gay men use condom for they concern more on the fulfillment of needs for varied sexual activities and strong intention to mutually satisfy without using condom. Enggarwati (2015), mentions that the level of severity of the disease toward either the disease it self and financial condition in terms of treatment cost, does not make gay men change their sexual behavior, their satisfaction makes them accept their fate with HIV/AIDS. 
Journal of Health Promotion and Behavior (2017), 2(1): 88-97

https://doi.org/10.26911/thejhpb.2017.02.01.08

\section{The influence of perceived benefits toward condom use among gay men.}

Perceived benefits influence the use of condom among gay men. Pelangi Community understood the benefits if using condom to protect themselves from sexual transmitted disease such as HIV/ AIDS. Sometimes they believed that condom they used did not leak and was able to protect their sexual organ from HIV/ AIDS when cuts and blisters occured during sexual intercourse. Meanwhile, they always got free condom from Tulungagung Regional AIDS Countermeasure Commission and they used it because they believed that their sexual partner was infected with HIV/AIDS and felt protected when they used condom.

People are likely to adopt healthy behavior when they believe the new behavior will reduce their possibility to get infected with a disease. People will not use condom if they do not believe the benefits of condom to prevent from being infected with HIV through sexual intercourse (Belcher et al., 2005).

The study is in accordance with Sirait et al (2013), that states there is significant relationship between perceive benefits and preventive behavior. The better one's positive perception is toward HIV/ AIDS preventive behavior, the bigger possibility to dothe behavior. Study by Satyabakti (2016), states that gay men are able to prevent and feel protected when they use condom during sexual intercourse.

The other study by Padang (2012), showed that there is no relationship between perceived benefits and the use of condom among gay men. They are reluctant to use it during sexual intercourse. It is because the existence of dominant factors of sexual satisfaction fulfillment, emotional satisfaction, inconvenient, and stigma over condom as the means to prevent HIV/AIDS infection.

\section{The influence of perceived obstac- les toward condom use among gay men}

Perceived obstacles have influence toward the use of condom. Pelangi Community had sexual behavior which is at high risk for being infected with HIV/ AIDS. By using condom will be able to prevent from being infected since condom limits skin to skin contact that reduce pleasure of sexual intercourse. They always get free condom and lubricant from the government which are distributed to the community

Rosenstock (1988), states that perceived obstacles is a determinant of behavioral change in order for the new behavior to get adopted. People needs to believe that benefits of new behavior is more than the old one.

Downing (2010), states that there is a relationship between perceived obstacles and condom use. Sexual activity which is conducted freely and at risk, is derived from lust and addiction followed by sexual arousalphase to get sexual satisfaction. Gay men do not concern about the risk of getting infected with STD and HIV/AIDS.

The study by Harawa et al (2006), states that the obstacles in using condom give bigger influence on the preventive behavior than threat of the disease it self. The obstacles are reducing the pleasure of sexual intercourse and being accused of having sexual transmitted disease.

Different study conducted by Priyoto (2014), states that an action is possible to be taken despite the individual's belief toward the advantage of taking the action. They have had the skills to negotiate with their partner that using condom will still lead to satisfaction and their partners are convinced to use condom during sexual intercourse. 


\section{The influence of self efficacy to- ward condom use among gay men}

The efficacy influences the condom use. In Pelangi Community almost all members could use condom appropriately. The information was obtained from the socialization for the appropriate use of condom from Tulungagung Regency Regional AIDS Countermeasure Commission or administrators of Pelangi Community who had joined seminars and trainings. They also often read the instructions how to appropriately use condom and lubricant from its packaging. In addition, they often held meetings in which they made competition on how to use condom appropriately and the winners were granted with prizes from Tulungagung Regional AIDS Countermeasure Commission or Tulungagung Health Office, who held the meetings.

Self efficacy is being added into the perceived Health Belief Model because in self efficacy it is resembling when someone believe to a new behavior but do not assume that he/ she is able to do it (seems there are obstacles) it is possible that it will not be conducted (Rosenstock et al., 1988).

It is accordance with the study by Syafri (2001), that shows the relationship between capability to use condom appropriately and intention to use condom consistently. Kawangung (2012), shows that there is an influence of information distribution about how to use condom appropriately and consistently among gay men toward self confident to always use condom each time they have sex.

The study by Kawangung (2012), points out the there is an influence of information distribution about how to use condom appropriately and consistently among gay men related to self confident to always use condom each time they have sex. The improved information among gay men also change the behavior of gay men who are fond of high risk sexual activities.

Different study conducted by Aditya (2012), that states the ability to use condom does not influence the use of condom. Gay man who is less proficient in negotiating with his partner make him does not use condom each time he has sexual intercourse.

\section{REFERENCE \\ Aditya ER (2012). Perilaku Penggunaan Kondom Secara Konsisten untuk Pen- cegahann HIV: Suatu Studi Kualitatif pada Pekerja Seks Laki-laki Berbasis Panti Pijat diJakarta. Tesis. Program ,Studi Ilmu Kesehatan Masyarakat. \\ Amirkhanian Y, Kelly J, Seal David, Galletly CM, DiFranceisco W, Glasman LR, Stevenson Y (2010). Levels and Pre- dictors of Sexual HIV Risk in Social Networks of Men Who Have Sex with Men in The Midwest. AIDS Educ Prev 22(6):483-95.doi:10.1521/aeap.2010.- 22.6.483.}

Belcher L, Sternberg MR, Wolotski RJ, Halkitis P, Hoff C (2005). Condom Use and Perceived Risk of HIV Transmission Among Sexually Active HIV Positive Men Who Have Sex with Men. AIDS Education and Prevention. AIDS Educ Prev 17(1): 79-89.DOI:10.1521/aeap.17.1.79.-58690.

Dinkes Jatim (2015). Profil Kesehatan Jawa Timur 2014. http://www.depkes.go.id/resources/download/profil/PR OFIL_KES_PROVINSI_2014/15_Jati $\mathrm{m} \_2014$.pdf. Diakses tanggal 7 November 2016.

Downing MJ (2010). Perception of Risk Sexual Behaviors and HIV Prevention: A Study of MSM. Dissertation School of The City University of New York 153-160. 
Journal of Health Promotion and Behavior (2017), 2(1): 88-97

https://doi.org/10.26911/thejhpb.2017.02.01.08

Eda N, Widjanarko B, Widagdo L (2012). Niat Penggunaan Kondom pada Komunitas Waria di Kota Ternate. Jurnal Promosi Kesehatan Indonesia 7 (2): 182 .

Enggarwati I (2015). Faktor-faktor yang Berhubungan dengan Perilaku Pencegahan Penularan HIV/AIDS pada Laki-laki Homoseksual Pekerja Seks di Kabupaten Kudus.

Harawa NT, William JK, Ramamurthi HC, Bingham TA (2006). Perceptions Towards Condom Use, Sexual Activity and HIV Disclosure Among HIV Positive African American Men Who Have Sex with Men: Implications for Heterosexual Transmission. Urban Health, Bulletin of the New York Academy of Medicine 83(4): 682-94.DOI:10.1007/s11524-006-9067-o.

Kawangung VY (2012). Pengaruh Ketersediaan Kondom Terhadap Penggunaan Kondom pada Seks Komersial di Lokasi Batu 24 dan Batu 8o Kabupaten Bintan Provinsi Kepri. Tesis. Universitas Indonesia.

Kemenkes RI (2014). Situasi dan Analisis HIV/AIDS Pusat Data dan Informasi Kementerian Kesehatan RI. http://www.depkes.go.id/resources/downloa d/pusdatin/infodatin/Infodatin\%20A IDS.pdf. Diakses tanggal 6 November 2016.

(2016). Laporan Kasus HIV/ AIDS di Indonesia Sampai dengan Desember 2016.http://spiritia.or-.id/Stats/detailstat.php?no=7.Diakses tanggal 8 November 2016.

Liu S, Chen L, Li L, Zhao J, Cai W, Rou K, Wu Z (2012). Condom Use with Various Types of Sex Partners by Money Boys in China. AIDS Educ Prev24(2):163-178. doi: 10.1521/-aeap.2012.24.2.163.
McCormick-Brown K (1999). Health Belief Model. http://hsc.usf.edu/kmbrown /Health_Belief_Model overview.htm. Diakses tanggal 24 November 2016.

McDaid LM, Hart GJ (2010). Sexual Risk Behaviour for Transmission of HIV in Men Who Have Sex with Men. Journal Sex Med 24: 311-316.

Padang J (2012). Persepsi Kaum Homoseksual terhadap Aktivitas Seksual yang BerisikoTerjadinya HIV/AIDS. Fakultas Ilmu Keperawatan UI.

Priyoto (2014). Teori Sikap dan Perilaku dalam Kesehatan. Yogyakarta: Nuha Medika.

RamanathanS, Chakrapani V, Ramakrishnan L, Goswami P, Yadav D, Subramanian T, George B (2013). Consistent Condom Use with Regular, Paying, and Casual Male Partners and Associated Factors Among Men Who Have Sex with Men in Tamil Nadu, India: Findings From an Assessment of a Large Scale HIV PreventionProgram. BMC Public Health13: 827. doi: 10.1186/1471-2458-13-827.

Rosenstock IM, Strecher VJ \& Becker MH (1988). Social Learning Theory and The Health Belief Model. Health Education Quarterl 15(2): 175-83.

Satyabakti N(2016). Perbedaan Penggunaan Kondom pada Gay terhadap Pasangan Tetap dan Pelanggan. Jurnal Berkala Epidemiologi 4(1): 87-99. Doi:10.20473-/jbe.v4il.

Sirait LM, Sarupaet S (2013). Hubungan Komponen Health Belief Model (HBM) dengan Penggunaan Kondom pada Anak Buah Kapal (ABK) di Pelabuhan Belawan. Jurnal Precure 1(1): 43-49.

Spiritia (2011). Peran Dukungan Sebaya terhadap Peningkatan Mutu Hidup ODHA di Indonesia. http://spiritia.or.id/dokumen/laporan penelitian 
peran dukungan sebaya.pdf. Diakses tanggal 27 November 2016.

(2012).Peningkatan Tingkat Hubungan Seks Tanpa Kondom di Kalangan PriaGayhttp://spiritia.or.id/news/bacanews.php?nwno=3043. Diakses tanggal 1 November 2016.

UNAIDS (2004).Position Statement on Condom and HIVPrevention http://data.unaids.org/unadocs/condom policy_julo4_en.pdf.Diakses tanggal 20 November 2016.

(2008). Report on The Global AIDSEpidemic. http://data.unaids.org/pub/GlobalReport/2008/JC1511_GRo8. Diakses tanggal 19 November 2016.
WHO (2009). Condom and HIV Prevention. http://www.who.int/hiv/pub/condoms/20090318_position_condoms.pdf. Diakses tanggal 19 November 2016.

(2015). Global Summary of The AIDS Epidemic 2015. http://www.who.int/hiv/data/epi_core_2016.png. Diakses tanggal 8 November 2016.

(2016). Global Health Sector Strategy on HIV 2016-2021 Toward Ending AIDS.http://apps.who.int/iris/bitstre am/10665/246178/1/WHO-HIV2016.05eng.pdf?ua $=1$. Diakses tanggal 27 November 2016. 